\title{
Optimalisasi Pendekatan Scientific dalam Pembelajaran Pendidikan Agama Islam
}

\author{
Sarini Musyafi'ah Ali \\ Institut Pesantren KH. Abdul Chalim \\ email: Sariniali6@gmail.com \\ Kartini Ponengoh \\ Email: Kartini_ponengoh@yahoo.com \\ MAN Model Manado
}

\begin{abstract}
This study serves to determine the extent of the use of scientific approaches in learning Islamic religious education. The method used in this research is to use library research or library research. Where research uses reference books, articles, and journals related to the research title. The 2013 curriculum is a development of the Competency Based Curriculum which was first released in 2004 which includes competency attitudes, knowledge, and skills by using a scientific approach in learning. Learning by using a scientific approach is a learning process that is designed so that students are actively involved in contradicting principles, concepts, or laws by going through several stages of learning activities. The work process of this approach is to prioritize the logic of inductive thinking rather than deductive. Learning with a scientific approach is a learning process that is designed so that students are actively involved in understanding the material without relying on information conveyed by the teacher. The learning step with a scientific approach includes observing, asking, trying, reasoning (associating), concluding, and communicating (forming networks). The use of the scientific approach is intended so that the material delivered by the teacher or educator can be understood by students. Before carrying out learning activities using a scientific approach, the teacher must make some preparations by preparing learning instruments such as lesson plans. Basically, all learning activities are left to each teacher to be able to develop innovation and creativity. although the preparation is not the same as the example, but it can provide a reference for the use of a scientific approach
\end{abstract}

Keywords: 2013 Curriculum, Scientific Approach, Learning, Islamic Religious Education 


\section{Pendahuluan}

Pendidikan di Indonesia bisa dilihat dari penyelenggaraan pendidikan seperti kurikulum. Mengingat kurikulum merupakan komponen yang paling pentiung dalam terlaksananta pendidikan. Keberhasilan tdari tujuan pendidikan sangat bergantung pada kurikulum yang diterapkan. Jika suatu kurikulum tidak diterapkan dalam pendidikan, maka pendidikan tersebut menjadi tidak jelas arahnya ${ }^{1}$.

Kurikulum merupakan suatu rencana yang disusun untuk melancarkan proses belajar mengajar di bawah bimbingan dan tanggung jawab sekolah yang bukan hanya meliputi semua kegiatan yang direncanakan, melainkan juga peristiwa-peristwa yang terjadi di bawah pengawasan sekolah. ${ }^{2}$ Pada kurikulum 2013 yang sangat ditekankan adalah pembelajaran yang menggunakan pendekatan scientific. Pendekatan ini sangat diprioritaskan dalam mengimplementasikan kurikulum $2013^{3}$.

Pembelajaran dengan pendekatan scientific merupakan proses ilmiah. Oleh sebab itu, Kurikulum 2013 menerapkan pendekatan scientific kedalam proses pembelajaran dengan menggunakan langkah $5 \mathrm{M}$ dalam kegiatan pembelajaran ${ }^{4}$. permendikbud No 65 Tahun 2013 tentang standar Proses Pendidikan dasar dan Menengah mengisyaratkan prose pembelajaran menggunakan pendekatan ini $^{5}$.

Pendekatan saintifik ini bukanlah sesuatu yang baru dalam proses pembelajaran. pendekatan ini sudah ada bersamaan dengan kurikulum 2013,

${ }^{1}$ Muhammad Anas Ma`arif dan Muhammad Husnur Rofiq, "Pola Pengembangan Kurikulum Pendidikan Pesantren Berkarakter: Studi Pondok Pesantren Nurul Ummah Mojokerto," TADRIS: Jurnal Pendidikan Islam 13, no. 1 (7 September 2018): 1-16, https://doi.org/10.19105/tjpi.v13i1.1635.

${ }^{2} \mathrm{~S}$. Nasution, Kurikulum Dan Pengajaran, (Jakarta: Bumi Aksara, 2010), 5

${ }^{3}$ Ishmatun Nihayah, "Pengembangan Kurikulum Bidang Studi Pendidikan Agama Islam Pada Program Akselerasi Di SMAN 5 Surabaya," Nazhruna: Jurnal Pendidikan Islam 1, no. 2 (19 November 2018): 312-23, https://doi.org/10.31538/nzh.v1i2.88.

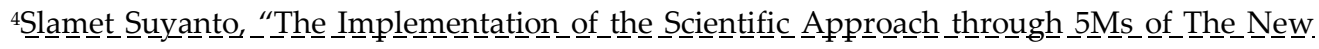

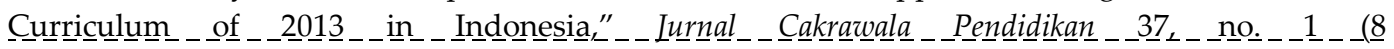

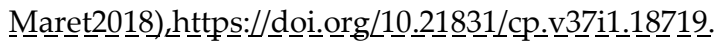

${ }^{5}$ Muhammad Nur Hakim dan Fitriyani Dwi Rahayu, "Pembelajaran Saintifik Berbasis Pengembangan Karakter," Nazhruna: Jurnal Pendidikan Islam 2, no. 1 (24 Februari 2019): 1-27, https://doi.org/10.31538/nzh.v2i1.148. 
karena pendekatan saintifik merupakan bagian dari kurikulum 2013. Dan pada dasarnya, pendekatan ini mengarahkan peserta didik agar mampu mermusukan masalah. Selain itu, peserta didik juga dilatih berpikir kritis dan analitis, yaitu diajarkan bukan hanya mendengarkan dan menghafalkan materi ajar tetapi diajarkan untuk mengambil keputusan. Proses pembelajaran dengan menerapkan pendekatan saintifik ini akaan berjalan baik apabila guru memahami dengan baik pendekatan saintifik ${ }^{6}$. Dengan demikian penulis tertarik untuk mengelaborasi dan menganalisis permasalahan pendekatan scientific dalam pembelajaran PAI.

\section{Pembahasan}

\section{Kurikulum 2013}

Seperti yang telah dipaparkan dalam UU Sisdiknas No 20 Tahun 2003 bahwa tujuan pendidikan nasional adalah:

untuk mengembangkan potensi yang dimiliki peserta didik agar menjadi manusia yang beriman dan bertakwa kepada Tuhan Yang Maha Esa, berakhlak mulia, sehat, berilmu, cakap, kreatif, mandiri dan menjadi warga negara yang demokratis serta bertanggung jawab. Untuk mencapai tujuan tersebut maka pendidikan tidak bisa terlepas dari kurikulum. Berhasil ataupun tidaknya pendidikan sangat tergantung pada kurikulum yang dipakai. Oleh sebab itu, kurikulum merupakan wadah dalam menentukan arah pendidikan.

Kurikulum merupakan alat untuk mencapai tujuan pendidikan. Untuk mencapai tujuan pendidikan tersebut, kurikulum harus bersifat dinamis dan berubah sesuai dengan perkembangan dan tuntutan pendidikan. Kurikulum di Indonesia telah mengalami banyak pengembangan. Dimulai sejak kurikulum 1964, kurikulum 1968, kurikulum 1975, kurikulum 1984, kurikulum 1994, kurikulum KBK (Kurikulum Berbasis Kompetensi) tahun 2004, kurikulum KTSP

\footnotetext{
${ }^{6}$ Fithri Nuru Ayuni, "Pemahaman Guru Terhadap Pendekatan Saintifik (Scientific Approach) Dalam Pembelajaran Geografi," Jurnal Geografi Gea 15, No. 2 (25 Agustus 2016): 3, Https://Doi.Org/10.17509/Gea.V15i2.3542.
} 
(Kurikulum Tingkat Satuan Pendidikan) tahun 2006, hingga yang terakhir adalah kurikulum 2013 yang implementasianya serentak dilaksanakan pada tahun $2014^{7}$.

Kurikulum 2013 meupakan kurikulum yang baru diterapkan pada tahun 2013/2014. Kurikulum ini merupakan pengembangan dari Kurikulum Berbasis Kompetensi yang sudah lebih dahulu dirilis pada tahun 2004 yang meliputi kompetensi sikap, pengetahuan, dan keterampilan. Kurikulum 2013 dirumuskan dan kemudian dikembangkan untuk menghasilkan lulusan sekolah yang sesuai dengan tujuan pendidikan nasional ${ }^{8}$.

Perbedaan antara kurikulum antara kurikulum 2013 dengan kurikulum sebelumnya adalah terletak pada proses pembelajarannya. Dalam proses pembelajaran Kurikulum 2013 menggunakan pendekatan ilmiah atau approach scientific ${ }^{9}$.

Mengenai tujuan Kurikulum 2013, secara khusus dapat diuraikan sebagai berikut:

1. Meningkatkan mutu pendidikan dengan menyeimbangkan hard and soft skill melalui kemampuan sikap,keterampilan, dan pengetahuan dalam rangka menghadapi tantangan global yang terus berkembang.

2. Membentuk dan meningkatkan sumber daya manusia yang produktif, kreatif, dan inovatif, sebagai modal pembangunan bangsa dan negara Indonesia ${ }^{10}$

Berdasarkan tujuan-tujuan di atas, maka dapat dipahami secara umum kurang lebih sama dengan tujuan KTSP. Hanya saja, dalam Kurikulum 2013 pemerintah lebih menekankan pada hard and soft skill peserta didik.

\section{Pendekatan Scientific}

\footnotetext{
${ }^{7}$ Yahfenel Evi Fussalam, “IMPLEMENTASI KURIKULUM 2013 (K13) SMP NEGERI 2 SAROLANGUN" 3, no. 1 (2018): 11.

${ }^{8}$ Imas Kurniasih, Berlin Sani, Sukses Mengimplementasikan Kurikulum 2013 Memahami Berbagai Aspek Dalam Kurikulum 2013, (Jakarta: Kata Pena: 2014), H. 1

${ }^{9}$ Zaenal Arifin, "PENDEKATAN PEMBELAJARAN SAINTIFIK PADA MATA PELAJARAN BAHASA ARAB DI MADRASAH," t.t., 20.

${ }^{10}$ E. Mulyasa, Pengembangan Dan Implementasi Kurikulum 2013, Cetakan Pertama (Bandung: Pt Remaja Rosdakarya, 2013).
} 
Pendekatan saintifik ini dipopulerkan pertama ke dunia pendidikan Amerika pada akhir abad ke-19 sebagai bentuk penekanan pada metode laboratorium yang mengacu pada fakta-fakta ilmiah ${ }^{11}$. Pembelajaran dengan pendekatan saintifik adalah proses pembelajaran yang dirancang agar peserta didik terlibat aktif dalam memahami materi tanpa bergantung pada informasi yang disampaikan oleh guru. Oleh karena itu, proses pembelajaran yang tercipta mampu mendorong peserta didik tidak hanya sekedar mengetahui tetapi peserta didik juga dituntut untuk bisa mencari tahu sumber informasi melalui pengamatan ${ }^{12}$.

Pendekatan scientific menurut Manser berasal dari dua kata pendekatan dan science yangbahasa Inggris yang berarti pengorganisasian pengetahuan melalui observasi dan test terhadap fakta atau realita. Pendekatan yang saat ini sedang dilakukan terkait dengan kurikulum 2013 adalah pendekatan saintifik.

Secara konseptual, pendekatan saintifik dianggap paling unggul daripada konsep-konsep sebelumnya, seperti elaborasi, eksplorasi, dan konfirmasi karena dalam pendekatan saintifik ini terdapat lima langkah pembelajaran yang membuat peserta didik menjadi lebih aktif dalam mengolah informasi yang diterimanya ${ }^{13}$.

Pendekatan saintifik ini sangat diperlukan sebagai penunjang terwujudnya semua ranah yang terdapat dalam kurikulum 2013. Karena kurikulum ini didalamnya memuat kebutuhan peserta didik dari segi materi ajarnya, sedangkan pada proses pembelajarannya memuat cara bagaimana siswa bisa menguasai materi pelajaran yang diajarkan. Strategi dan pendekatan ini tidak akan berjalan efektif tanpa ada campuran tangan guru sebagai pelaksana. Mengingat tugas guru adalah mengembangakn dan menjalankan pendekatan saintifik disekolah baik secara individu ataupun kelompok ${ }^{14}$.

${ }^{11}$ Dika Setiawan, "Pendekatan Saintifik Dan Penilaian Autentik Untuk Meningkatkan Mutu Pembelajaran Pendidikan Agama Islam," Al-Asasiyya: Journal Of Basic Education 1, No. 2 (10 November 2017), Https://Doi.Org/10.24269/Ajbe.V1i2.683.

${ }^{12}$ Suyanto, "The Implementation of the Scientific Approach through $5 \mathrm{Ms}$ of The New Curriculum of 2013 in Indonesia."

${ }^{13}$ Imam Ghozali, "Pendekatan Scientific Learning Dalam Meningkatkan Prestasi Belajar Siswa" 04, No. 01 (2017): 4.

${ }^{14}$ Yarhamna Yarhamna Dkk., "Pengujian Praktikalitas Model Kegiatan Ekstrakurikuler Pendidikan Agama Islam Berbasis Pendekatan Saintifik Untuk Sekolah Dasar," Ta'dib 22, No. 1 (29 Juni 2019): 15, Https://Doi.Org/10.31958/Jt.V22i1.1446. 
Pendekatan saintifik ini merupakan salah satu pendekatan yang menitik beratkan pada pentingnya kerja sama antar peserta didik ${ }^{15}$.Pembelajaran saintifik merupakan proses pembelajaran yang membuat peserta didik lebih kreatif dan lebih aktif dengan menggunakan sains sebagai metode ataupun pendekatan dalam proses pembelajaran $^{16}$.

Prinsip dasar pembelajaran menggunakan pendekatan saintifik dalam kegiatan belajar mengajar yang menerapkan langkah-langkah kerja seperti pada pembelajaran kontekstual, pendekatan saintifik juga menggunakan beberapa strategi pembelajaran. Di dalam strategi juga terdapat model-model pembelajaran misalnya discovery learning, project-based learning, problem based learning, inquiry learning.

Dalam pendekatan saintifik ada beberapa tahap/ kegiatan, yaitu: Observing, Questioning, Associating, Experimenting, Processing, Conclusing, Presenting. Pembeelajaran dengan menggunakan pendekatan saintifik memiliki karakteristi berikut: berpusat pada siswa, melibatkan proses kognitif, mengembangkan karakter siswa.

Pendekatan saintifik atau pendekatan ilmiah diyakini adalah langkah terbaik untuk melakukan pengembangan dalam 3 ranah pendidikan, yaitu sikap, pengetahuan, dan keterampilan. Proses kerja dari pendekatan ini adalah mengutamakan logika berpikir induktif daripada deduktif. Logika berpikir induktif melihat fenomena dari yang khusus dan menarik kesimpulan secara keseluruhan sedangkan logika berpikir deduktif melihat fenomena umum untuk ditarik kesimpulan secara khusus ${ }^{17}$.

Pendekatan saintifik ini lebih menekankan pada proses akhir dari belajarlah yang sangat penting bukan pada hasil belajar yang menjadi target

\footnotetext{
${ }^{15}$ Fadhilaturrahmi Fadhilaturrahmi, "Penerapan Pendekatan Saintifik Untuk Meningkatkan Kemampuan Komunikasi Matematik Peserta Didik Di Sekolah Dasar," Eduhumaniora I Jurnal Pendidikan Dasar Kampus Cibiru 9, No. 2 (13 Juli 2017): 109, Https://Doi.Org/10.17509/Eh.V9i2.7078.

${ }^{16}$ Ayuni, "PEMAHAMAN GURU TERHADAP PENDEKATAN SAINTIFIK (SCIENTIFIC APPROACH) DALAM PEMBELAJARAN GEOGRAFI," 3.

${ }^{17}$ Arifin, "PENDEKATAN PEMBELAJARAN SAINTIFIK PADA MATA PELAJARAN BAHASA ARAB DI MADRASAH."
} 
peserta didik. Dalam artian, pendekatan ini lebih mengutamakan proses pencarian ilmu pengetahuan dari proses transfer ilmu pengetahuan ${ }^{18}$

Ditinjau dari klasifikasi pendekatan, pendekatan ini termasuk dalam pendekatan yang berpusat pada siswa, karena proses pembelajaran guru hanya sebagai fasilitator dan peserta didik yang terlibat secara aktif mengolah informasi ${ }^{19}$. Sedangkan jika ditinjau dari sudut pandang proses, pendekatan ini pada dasarnya merupakan pendekatan yang menerapkan langkah-langkah kerja ilmiah $^{20}$.

Pembelajaran dengan menggunakan pendekatan saintifik adalah proses pembelajaran yang dirancang agar peserta didik terlibat aktif menkonturksi prinsip, konsep, ataupun hukum dengan melalui beberapa tahapan-tahapan kegiatan pembelajaran ${ }^{21}$ Pendekatan saintifik ini dimaksudkan untuk memberikan pemahaman kepada peserta didik dalam mengenal, memahami, berbagai materi menggunakan pendekatan ilmiah, bahwa informasi bisa berasal dari mana saja, kapan saja, tidak bergantung pada informasi searah dari guru ${ }^{22}$.

Dalam Proses pembelajaran kurikulum 2013 semua jenjang pendidikan menggunakan pendekatan saintifik. Pembelajaran dengan pendekatan saintifik ini menyentuh 3 ranah pendidikan, yaitu ranah sikap, ranah pengetahuan, dan ranah keterampilan $^{23}$.

Berdasarkan Peraturan Menteri Pendidikan dan Kebudayaan Nomor 22 Tahun 2016, disebutkan langkah pembelajaran dengan pendekatan saintifik

\footnotetext{
${ }^{18}$ Kusaeri Kusaeri dan Rangga Sa'adillah, "Telaah Epistemologis Pendekatan Saintifik Mata Pelajaran Pendidikan Agama Islam," ISLAMICA: Jurnal Studi Keislaman 9, no. 2 (7 September 2015): 348, https://doi.org/10.15642/islamica.2015.9.2.344-372.

${ }^{19}$ Deti Rostika Dan Prihantini Prihantini, "Pemahaman Guru Tentang Pendekatan Saintifik Dan Implikasinya Dalam Penerapan Pembelajaran Di Sekolah Dasar," Eduhumaniora I Jurnal Pendidikan Dasar Kampus Cibiru 11, No. 1 (31) Januari 2019):88,Https://Doi.Org/10.17509/Eh.V11i1.14443.

${ }^{20}$ Rudi Susilana, "Pendekatan Saintifik dalam Implementasi Kurikulum 2013 Berdasarkan Kajian Teori Psikologi Belajar," edutech 13, no. 2 (2014): 183-193.

${ }^{21}$ A. Machin, "Implementasi Pendekatan Saintifik, Penanaman Karakter Dan Konservasi Pada Pembelajaran Materi Pertumbuhan," Jurnal Pendidikan Ipa Indonesia 3, No. 1 (2014): 28, Https://Doi.Org/10.15294/Jpii.V3i1.2898.

${ }^{22}$ M. Hosnan, Pendekatan Saintifik Dan Kontekstual Dalam Pembelajaran Abad 21: Kunci Sukses Implementasi Kurikulum 2013, Cet. Pertama (Ciawi, Bogor: Ghalia Indonesia, 2014), 34.

${ }^{23}$ Rostika Dan Prihantini, "Pemahaman Guru Tentang Pendekatan Saintifik Dan Implikasinya Dalam Penerapan Pembelajaran Di Sekolah Dasar."
} 
meliputi mengamati, menanya, mencoba, menalar (mengasosiasi), menyimpulkan, serta mengkomunikasikan (membentuk jejaring). Lima langkah ini dikenal dengan istilah 5M. Langkah-langkah dalam pembelajaran menggunakan pendekatan saintifik disajikan ${ }^{24}$ sebagai berikut:

1. Mengamati.

Metode mengamati mengutamakan kebermaknaan proses pembelajaran. metode ini memiliki keunggulan seperti, menyajikan media obyek secara nyata, peserta didik senang dan tertantang, dan mudah pelaksanaannya. Dengan metode observasi peserta didik menemukan fakta bahwa ada hubungan antara obyek yang dianalisi dengan materi yang diajarkan guru. Metode ini juga melibatkan secara langsung peserta diidk dalam pembelajaran

2. Menanya

Guru yang efektif mampu menginspirasi peserta didik untuk meningkatkan dan mengembangkan ranah sikap, keterampila, dan pengetahuannya. Langkah ini dimaksudkan agar peserta didik mampu mengembangkan kreatifitas dan rasa ingin tahunya serta mampu merumuskan pertanyaan untuk membentuk pikiran yang kritis.

3. Mengumpulkan informasi

Kegiatan mengumpulkan informasi merupakan tindak lanjut dari kegiatan bertanya. Dalam permendikbud No 81 a tahun 2013, aktivitas mengumpulkan informasi dilakukan melalui kegiatan eksperimen, dengan mengamati objek atau kejadian. Adapaun kompetensi yang diharapkan adalah mampu mengembangkan sikap teliti, jujur, sopan, menghargai pendapat orang lain, kemampuan berkomunikasi, dan mengembangkan kebiasaan belajar sepanjang hayat.

4. Mengasosiasikan

Dalam permendikbud No 81 a Tahun 2013 kegiatan mengasosiasi adalh memproses informasi yang sudah dikumpulkan baik terbatas dari hasil 
kegiatan eksperimen maupun hasil dari kegiatan dan kegiatan mengumpulkan informasi. Adapun kompetensi yang diharapkan adalah mengembangkan sikap jujur, teliti, disiplin, taat aturan,kerja keras, kemampuan menerapkan prosedur dan kemampuan berpikir induktif serta deduktif dalam menyimpulkan.

\section{Menarik kesimpulan}

Kegiatan menyimpulkan dalam pembelajaran dengan pendekatan saintifik merupakan kelanjutan dari kegiatan mengolah data atau informasi. Setelah menemukan keterkaitan antar informasi dan menemukan berbagai pola dari keteratrikan tersebut, selanjutnya secara bersama-sam dalam satu kesatuan kelompok, atau secara individual membuat kesimpulan.

6. Mengkomunikasikan

Pada pendekatan saintifik guru diharapkan memberi kesempatan kepada peserta didik untuk mengkomunikasikan yang telah dipelajari. Kegiatan ini dapat dilakukan melalui menuliskan aatau menceritakan apa yang ditemukan dalam kegiatan mencari informasi, mengasosiasikan dan menemukan pola. Adapun kompetensi yang diharapkan dalam kegiatan ini adalah mengmebangkan sikap jujur, teliti, toleransi, kemampuan berpikir sistematis, mengungkapkan pendapat dengan singkat dan jelas dan mengembangkan kemampuan berbahasa yang baik dan benar ${ }^{25}$.

Adapun Kriteria pendekatan saintifik ${ }^{26}$ yang terdapat pada Kemendikbud (2013) sebagai berikut:

a. Materi pembelajaran berbasis pada fakta atau fenomena yang dapat dijelaskan dengan logika atau penalaran tertentu; bukan sebatas kira-kira, khayalan, legenda atau dogeng.

\footnotetext{
${ }^{25}$ Imas Kurniasih, 55

${ }^{26}$ Arifin, "PENDEKATAN PEMBELAJARAN SAINTIFIK PADA MATA PELAJARAN BAHASA ARAB DI MADRASAH."
} 
b. Penjelasan guru, respon siswa, dan interaksiedukatif guru siswa terbebas dari prasangka yang serta pemikiran subjektif, atau penalaran yang menyimpang dari alur berpikir logis.

c. Mendorong dan meninspirasi siswa berpikir secara kritis, analitis dan tepat dalam mengidentifikasi, memahami, memecahkan masalah, dan mengaplikasikan materi pembelajaran.

d. Mendorong dan menginpirasi siswa mampu berpikir hipotetik dalam melihat perbedaan, kesamaan, dan tautan satu sama lain dari materi pembelajaran.

e. Mendorong dan menginspirasi siswa mampu memahami, menerapkan, dan mengembangkan pola berpikir yang rasional dan objektif dalam merespon materi pelajaran.

f. Berbasis pada konsep, teori dan fakta empiris yang dapat dipertanggung jawabkan.

g. Tujuan pembelajaran dirumuskan secara sederhana dan jelas, namun menarik sistem penyaji.

Didasari pada keunggulan pendekatan ini, tujuan pembelajaran dengan menggunakan pendekatan saintifik ialah: (1) meningkatkan kemampuan intelektual, kemampuan siswa dalam berpikir tingkat tinggi (2) membentuk kemampuan siswa dalam menyelesaikan masalah secara sistemetik, (3) terciptanya kondisi pembelajaran yang menyenangkan, (4) memperoleh hasil belajar yang tinggi, (5)mampu mengkomunikasikan ide-ide yang dimiliki, (6) mengembangkan karakter ${ }^{27}$.

Pendekatan saintifik dan tiga teori belajar sangat relevan, yaitu teori Bruner, Piaget, dan Vygotsky. Dalam teori Bruner ada empat hal poko yang sangat berkaitan dengan pendekatan saintifik. Pertama, individu hanya belajar dan mengembangkan pikirannya apabila ia menggunakan pikirannya. Kedua, dengan

\footnotetext{
${ }^{27 M a c h i n, ~ " I m p l e m e n t a s i ~ P e n d e k a t a n ~ S a i n t i f i k, ~ P e n a n a m a n ~ K a r a k t e r ~ D a n ~ K o n s e r v a s i ~ P a d a ~}$ Pembelajaran Materi Pertumbuhan," 28.
} 
melakukan proses kognitif, siswa akan memperoleh sensasi dan kepuasan intelektual. Ketiga, memiliki kesempatan untuk melakukan penemuan. Keempat, dengan penemuan, bisa memperkuat potensi ingatan. Empat hal di atas memiliki kesesuaian dengan proses kognitif yang diperlukan dalam pembelajaran menggunakan pendekatan saintifik ${ }^{28}$.

Dan di dalam teori piaget diungkapkan bahwa proses pembelajaran tidak akan berjalan lancar apabila tidak ada stimulus dari lingkungan sekitarnya. Dalam teori ini, Piaget mengemukakan tahapan-tahapan seseorang dalam mengolah informasi yang diterima. Tahapan-tahapan tersebut ialah: mengamati, merumuskan hipotesis, merumuskan masalah, mengumpulkan dan menganalisis data serta kemudian ditarik kesimpulan. Sehingga bisa dikatakan bahwa pendekatan saintifik ini selalu melibatkan proses asimilasi dan akomodasi. Sedangkan Vygotsky sendiri mengemukakan bahwa pembelajaran terjadi apabila peserta didik mampu memecahkan tugas-tugas yang diberikan dengan bantuan bimbingan dari orang yang lebih mampu dari dia.

\section{Pembelajaran PAI}

Sebelum masuk lebih jauh pada pengertian PAI, saya akan menjelaskan sedikit tentang perbedaan antara Pendidikan Agama Islam dengan Pendidikan Islam. Pendidikan Islam itu mencakup dengan keseluruhan dari pendidikan itu sendiri. Seperti kurikulum, Sapras, kepemimpinan, manajemen, peserta didik, dan pendidikan. Sedangkan PAI merupakan salah satu bagian dari kurikulum pendidikan islam. Pendidikan agama Islam merupakan bagian kecil dari sitem pendidikan Islam. Pendidikan agama islam termasuk sebagai kelompok ilmu agama yang diajarkan kepada siswa. Jadi, Pendidikan agama Islam adalah suatu mata pelajaran yang mengkaji hal ihwal ilmu agama Islam seperti aqidah akhlak, SKI, Fiqh, dan Al-quran Hadits ${ }^{29}$

\footnotetext{
${ }^{28}$ Hosnan, Pendekatan Saintifik Dan Kontekstual Dalam Pembelajaran Abad 21, 35.

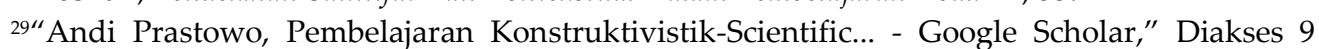
Oktober 
Pendidikan Agama Islam merupakan sesuatu yang sudah ditetapkan oleh nabi dalam sebuah haditsnya "menuntut ilmu merupakan kewajiban bagi setiap muslim” (HR. Ibnu Adi dan Baihaqi). Sabda Nabi SAW., menjelaskan bahwa umat Islam adalah umat yang mencintai ilmu pengetahuan.

Istilah pendidikan dalam konteks Islam pada umumnya mengarah padaaltarbiyah, al-ta'lim dan al-ta'dib. Ketiga istilah tersebut yang sangat populer dalam dunia pendidikan islam adalah kata al-tarbiyah, sedangkan 2 kata lainnya jarang digunakan ${ }^{30}$. Istilah al-Tarbiyah sudah tidak asing lagi dalam khazanah pendidikan Islam, terutama dalam pendidikan Indonesia. Begitu populernya istilah tersebut sehingga digunakan sebagai nama fakultas di Perguruan Tinggi Agama Islam atau yang biasa kita dengar Fakultas Tarbiyah dan Ilmu Keguruan, dengan jurusan kependidikan dan keguruan dibawah naungannya ${ }^{31}$

Istilah al-Tarbiyah merujuk pada QS al-Imran ayat 79\&146 merupakan proses mentransfer ilmu pada peserta didik dari tingkatan paling dasar sampai tingkatan tertinggi guna memberikan pembinaan dalam mendalami kehidupannya agar menjadi pribadi yang berbudi pekerti luhur sehingga dapat meningkatkan ketakwaann kepada Allah dengan kesempurnaan ilmu yang dimiliki ${ }^{32}$.

Pada dasarnya pendidikan agama Islam merupakan usaha seorang muslim dewasa yang secara sadar mengarahkan, membimbing kemampuan dasar peserta didik melalui ajaran Islam untuk mencapai titik maksimal pertumbuhan dan perkembangannya ${ }^{33}$ Beranjak dari pengertian diatas, dapat ditarik benang merah bahwa Pendidikan Agama Islam merupakan proses membimbing peserta didik agar menjadi pribadi yang sesuai dengan ajaran yang terdapat dalam Al-Quran

\footnotetext{
Https://Scholar.Google.Co.Id/Scholar?Hl=En\&As_Sdt=0\%2c5\&Q=Andi+Prastowo\%2c+Pembelajara n+Konstruktivistik-

Scientific+Untuk+Pendidikan+Agama+Di+Sekolah $\% 2$ fmadrasah+\%E2\%80\%9cteori $\% 2 \mathrm{c}+$ Aplikasi $\% 2$ $\mathrm{c}+$ Dan+Riset+Terkait $\% 2 \mathrm{c}+\% 28$ jakarta $\% 3 \mathrm{a}+$ Raja+Grafindo+Persada $\% 3 \mathrm{~b}+2015 \&$ Btng $=$.

${ }^{30}$ Abdul Halim, Filsafat Pendidikan Islam: Pendekatan Historis, Teoritis Dan Praktis (Jakarta: Ciputat Pers, 2002), 25

${ }^{31}$ Heri Gunawan, "Pendidikan Islam Kajian Teoritis Dan Pemikiran Tokoh," Bandung: Pt Remaja Rosdakarya, 2014, 2.

${ }^{32}$ Gunawan, 3.

33“Farid Hasyim, Kurikulum Pendidikan Agama Islam, Filosofi... - Google Scholar," 49, Diakses 9 Oktober 2019,Https://Scholar.Google.Co.Id/Scholar?Hl=En\&As_Sdt=0\%2c5\&Scioq=
} 
dan As-Sunnah Berdasarkan pendapat para ahli di atas, penulis menyimpulkan bahwa pendidikan islam adalah suatu yang memungkinkan peserta didik dengan mengarahkan kehidupannya sesuai ideologi islam dan pendidikan islam itu sendiri ditujukan pada perubahan sikap mental demi mewujudkan keperluan diri-sendiri dan orang lain yang berkaitan dengan amal perbuatan ${ }^{34}$.

\section{Tujuan Pendidikan Agama Islam}

Dalam proses pendidikan, tujuan pendidikan merupakan sesuatu yang urgen. Karena tujuan pendidikan merupakan aktualisasi nilai-nilai pendidikan yang hendak diwujudkan melalui pribadi peserta didik.

Tujuan pendidikan tidak lain dan tidak bukan adalah untuk memanusiakan manusia. Tujuan pendidikan Agama Islam ialah serangkaian proses pendidikan yang agama Islam yang ingin dicapai oleh sekolah ataupun madrasah ${ }^{35}$.

Sebagaimana tujuan pendidikan yang tercantum dalam Sistem Pendidikan Nasional ${ }^{36}$ BAB II pasal 3 yang berbunyi:

Pendidikan nasional berfungsi mengembangkan kemampuan dan watak serta mencerdaskan kehidupan bangsa Indonesia, bertujuan mengembangkan potensi peserta didik agar menjadi pribadi yang bertaqwa kepada Tuhan Yang Maha Esa,berakhlak mulia, kreatif, cakap dalam segala hal, memiliki ilmu pengetahuan, mandiri, dan bertanggung jawab serta bisa menjadi warga negara yangdemokratis

Sedangkan jika dicermati dari al-Quran dan as-Sunnah, tujuan pendidikan pada dasarnya terbagi menjadi 3 bagian. Pertama, membentuk insan kamil yang berakhlak qurani dan berbudi pekerti luhur. Kedua, terciptanya pribadi yang

\footnotetext{
${ }^{34}$ Anggun Wulan Fajriana dan Mauli Anjaninur Aliyah, “Tantangan Guru Dalam Meningkatan Mutu Pendidikan Agama Islam Di Era Melenial," Nazhruna: Jurnal Pendidikan Islam 2, no. 2 (11 Agustus 2019): 246-65, https://doi.org/10.31538/nzh.v2i2.324; Muhammad Ridwan, “Konsep Tarbiyah, Ta'lim Dan Ta'dib Dalam Al-Qur'an," Nazhruna: Jurnal Pendidikan Islam 1, no. 1 (16 Agustus 2018): 35-57, https://doi.org/10.31538/nzh.v1i1.41.

${ }^{35}$ Heri Gunawan, "Kurikulum Dan Pembelajaran Pendidikan Agama Islam. Cet," Ke-2. Bandung: Alfabeta, 2013, 205.

${ }^{36}$ U. U. Depdiknas Dan R. I. No, “Tahun 2003,” Tentang Sistem Pendidikan Nasional, 3
} 
kaffah baik dalam agama, budaya, maupun ilmu. Ketiga, sebagai hamba Allah dan khilafah di muka bumi sesuai dengan QS al-Baqarah: 30

Secara umum tujuan pendidikan agama Islam adalah untuk meningkatkan rasa keimanan, pengamalan, serta penghayatan peserta didik tentang ajaran agama Islam, sehingga menjadi pribadi yang berakhlak mulia dan bertaqwa kepada Allah SWT, serta menjadi pribadi yang Insan kamil baik di kehidupan pribadi, masyarakat, bangsa ataupun negara ${ }^{37}$.

\section{Pendekatan scientific dalam Pembelajaran Pendidikan Agama Islam}

Peran guru sangat diperlukan dalam melaksanakan proses pembelajaran, namun seiring dengan berjalannya waktu bantuan guru akan berkurang jika peserta didik bertambah dewasa ${ }^{38}$.

Hal ini sesuai dengan Permendikbud No 22 tahun 2016 yang meliputi mengamati, menanya, mencoba, menalar, menyimpulkan, serta mengkomunikasikan. Langkah-langkah kerja ini dikenal dengan istilah $5 \mathrm{M}^{39}$.

Penggunaan pendekatan saintifik ini bertujuan agar materi yang disampaikan oleh guru atau pendidik bisa dipahami siswa. Penggunaan pendekatan saintifik dalam pembelajaran juga bertujuan untuk mencapai suatu kompetensi. Harapannya setelah pembelajaran akan terjadi perkembangan kreativitas siswa, rasa ingin tahu siswa meningkat, siswa mampu mengajukan pertanyaan, dan mempunyai keterampilan berpikir kritis sehingga mempunyai manfaat dalam hidupnya ${ }^{40}$

\footnotetext{
${ }^{37}$ Muhaimin Dkk., Paradigma Pendidikan Islam: Upaya Mengefektifkan Pendidikan Agama Islam Di Sekolah (Remaja Rosdakarya, 2001). 78

${ }^{38}$ Diyah Ery Meliana, “Diajukan Kepada Universitas Negeri Surabaya Untuk Memenuhi Persyaratan Penyelesain Program Sarjana Pendidikan Luar Biasa," T.T., 5.

${ }^{39}$ Rudi Susilana, "Pendekatan Saintifik Dalam Implementasi Kurikulum 2013 Berdasarkan Kajian Teori Psikologi Belajar," Edutech 13, No. 2 (12 Agustus 2014):183,Https://Doi.Org/10.17509/Edutech.V13i2.3095.

${ }^{40}$ Nur Wakhidah, "Pembelajaran Dengan Pendekatan Saintifik Terhadap Kemampuan Berpikir Kritis Mahasiswa Calon Guru Madrasah Ibtidaiyah," Premiere Educandum: Jurnal
} 
Mengingat pendekatan saintifik ini lebih menekankan proses pembelajaran yang menyenangkan. Sehingga guru atau pendidik harus memiliki kemampuan pengelolaan kelas dengan baik agar pembelajaran menjadi lebih efektif dan tujuan yang telah tercantum dalam RPP bisa terwujud.

Dalam kurikulum 2013 ini peserta didik dituntut agar mampu mengembangkan kreatifitas yang dimilikinya. Dalam artian, peserta didik harus menjadi lebih aktif dalam mengolah materi yang diperoleh agar mereka menjadi mandiri dalam menyelesaikan masalah yang dihadapinya. Oleh sebab itu, guru harus bisa menjadikan proses pembelajaran lebih kreatif dan tidak monoton saja. Serta melibatkan peserta didik secara aktif dalam setiap kegiatan pembelajaran.

Kegiatan pembelajaran meliputi 3 kegiatan pokok, yaitu kegiatan pendahuluan, kegiatan inti, dan kegiatan penutup. Kegiatan pendahuluan bertujuan untuk menciptakan suasana awal pembelajaran yang efektif yang memungkinkan siswa dapat mengikuti proses pembelajaran dengan baik. Dalam pendekatan saintifik tujuan utamanya adlaah memantapkan pemahaman siswa terhadap konsep-konsep yang telah dikuasai berkaitan dengan materi pelajaran baru yang akan dipelajari siswa. Pada kegiatan pendahuluan, guru menunjukkan kejadian yang dapat menimbulkan pertanyaan dari siswa.

Kegiatan inti merupakan kegiatan utama dalam proses pembelajaran. kegiatan inti dalam pendekatan saintifik ditujukan untuk terkonstruksinya konsep, hukum atau prinsip oleh siswa dengan bantuan dari guru melalui langkah-langkah kegiatan yang diberikan. Sedangkan kegiatan penutup ditujukan untuk dua hal pokok. Pertama, validasi terhadap konsep, hukum dan prinsip. Kedua, pengayaan materi pelajaran yang dikuasai siswa ${ }^{41}$.

Sebelum melakukan kegiatan pembelajaran menggunakan pendekatan saintifik, guru harus melakukan beberapa persiapan dengan menyiapkan intrumen

\begin{tabular}{l}
\hline $\begin{array}{l}\text { Pendidikan Dasar Dan } \\
\text { 152,Https://Doi.Org/10.25273/Pe.V8i2.2950. }\end{array}$ \\
${ }^{41}$ Imas Kurniasih, 56
\end{tabular}


Optimalisasi Pendekatan Scientific dalam Pembelajaran. . . | 215 - 222

pembelajaran seperti RPP . berikut adalah contoh RPP yang menggunakan lima langkah pembelajaran: 


\section{RPP (Rancangan Pelaksanaan Pembelajaran)}

Sekolah

: MTs/SMP

Mata Pelajaran : PAI

Kelas/Sms $\quad$ : IX/1

Materi Pokok : Menghargai perilaku toleran dan menghargai perbedaan dalam pergaulan di sekolah dan masyarakat sebagai implementasi dari pemahaman Q.S. Al-Hujurat (49): 13 dan hadits terkait.

Alokasi Waktu : 1 Pertemuan 3JP

\section{A. Kompetensi Inti}

KI 1 : Menghargai dan menghayati ajaran agama yang dianutnya.

KI 2 : Menghargai dan menghayati perilaku jujur, disiplin, bertanggung jawab, peduli, (toleransi, gotong royong), santun, percaya diri dalam berinteraksi secara efektif dengan lingkungan sosial dan alam dalam jangkauan pergaulan dan keberadaannya.

KI 3 : Memahami pengetahuan (faktual, konseptual, dan prosedural) berdasarkan rasa ingin tahunya tentang ilmu pengetahuan, teknologi, seni, budaya terkait fenomena dan kejadian tampak mata.

KI 4 : Mencoba, mengolah, dan menyaji dalam ranah konkret (menggunakan, mengurai, merangkai, memodifikasi, dan membuat) dan ranah abstrak (menulis, membaca, menghitung, menggambar, dan mengarang) sesuai dengan yang dipelajari di sekolah dan sumber lain yang sama dalam sudut pandang/teori.

\section{B. Kompetensi Dasar}

1.2 Menghargai Al-Qur' an sebagai implementasi dari pemahaman rukun iman

2.2 Menghargai perilaku toleran dan menghargai perbedaan dalam pergaulan di sekolah dan masyarakat 
Optimalisasi Pendekatan Scientific dalam Pembelajaran. . . | 217 - 222

\section{Indikator}

3.2.1 Peserta didik mampu menemukan arti toleransi, macam-macam toleransi dan perilaku toleransi dalam kehidupan

3.2.2 Peserta didik mampu menghargai perilaku toleransi dan menghargai perbedaan dalam pergaulan di sekolah dan masyarakat

\section{Materi Pembelajaran}

1. Pengertian Toleransi dan menghargai perbedaan.

2. Macam-macam toleransi

3. Ulangan Harian

\section{E. Langkah-Langkah Kegiatan Pembelajaran}

a. Pendahuluan (10 menit)

1) Guru membuka pembelajaran dengan salam dan berdoa bersama dipimpin oleh seorang peserta didik dengan penuh khidmat.

2) Guru memulai pembelajaran dengan pembacaan al-Quran surah ayat pilihan yang dipimpin oleh salah seorang peserta didik.

3) Guru memperhatikan kesiapan diri peserta didik dengan mengisi lembar kehadiran dan memeriksa kehadiran, kerapian pakaian, posisi, dan tempat duduk peserta didik.

4) Guru memberikan motivasi dan mengajukan pertanyaan secara komunikatif yang berkaitan dengan toleransi.

5) Guru menyampaikan kompetensi dasar dan tujuan pembelajaran yang akan dicapai.

6) Guru mengkondisikan peserta didik untuk duduk secara berkelompok.

7) Menyampaikan tahapan kegiatan yang akan dilaksanakan dalam pembelajaran. 
8) Guru membagi siswa menjadi beberapa kelompok

b. Kegiatan inti (90 menit)

1) Mengamati:

a) Guru menyajikan gambar tentang toleransi

b) Peserta didik mengamati tayangan gambartoleransi

2) Menanya:

a) Guru memberi kesempatan peserta didik untuk menyampaikan gambar toleransi

b) Guru memberi kesempatan kepada peserta didik untuk mengajukan pertanyaan mengenai toleransi

c) Guru memberi kesempatan kepada peserta didik menyampaikan pendapat atau menjawab pertanyaan yang disampaikan oleh peserta didik lain

d) Peserta didik mengajukan pertanyaan sebanyak-banyaknya tentang toleransi

3) Eksplorasi

a) Peserta didik dalam beberapa kelompok dan diberikan tugas untuk berdiskusi sesuai dengan tema yang telah ditentukan (pengertian, macammacam, dalil aqli dan naqli, ciri-ciri perilaku dan hikmah toleransi)

4) Asosiasi:

a) Setiap kelompok membuat simpulan mind mappingmenghubungkan pengertian, dalil aqli dan naqli, ciri-ciri perilaku dan hikmah toleransi

5) Komunikasikan:

a) Secara bergantian masing-masing kelompok mempresentasikan hasilnya dan kelompok lainnya memperhatikan/menyimak dan memberikan tanggapan. 
c. Penutup (20 menit)

1) Guru memberikan penguatan materi tentang toleransi

2) Guru bersama-sama peserta didik menyimpulkan hasil diskusi peserta didik.

3) Guru melakukan tes evaluasi terhadap pemahaman peserta didik selama proses pembelajaran.

4) Guru bersama-sama para peserta didik melakukan refleksi terhadap pembelajaran yang telah dilaksanakan.

5) Guru memberikan reward kepada "kelompok peserta didik terbaik".

6) Guru menyampaikanmateri yang akandipelajari pada pertemuan berikutnya.

7) Guru memberikan tugas mandiri kepada peserta didik berkaitan dengan materi yang akandipelajari pada pertemuan berikutnya.

8) Guru bersama-sama para peserta didik menutup pelajaran dengan berdoa

Demikianlah contoh pembelajaran menggunakan pendekatan saintifik dalam pembelajaran PAI. Pada dasarnya, semua kegiatan pembelajaran diserahkan kepada setiap guru agar bisa melakukan pengembangan inovasi dan kreatifitas. meskipun penyusunannya tidak sama seperti yang dicontohkan, tetapi bisa memberikan acuan penggunaan pendekatan saintifik.

\section{Kesimpulan}

Dalam Proses pembelajaran kurikulum 2013 semua jenjang pendidikan menggunakan pendekatan saintifik. Pembelajaran dengan pendekatan saintifik ini menyentuh 3 ranah pendidikan, yaitu ranah sikap, ranah pengetahuan, dan ranah keterampilan. Pembelajaran dengan pendekatan saintifik adalah proses pembelajaran yang dirancang agar peserta didik terlibat aktif dalam memahami materi tanpa bergantung pada informasi yang disampaikan oleh guru.Penggunaan pendekatan saintifik ini bertujuan agar materi yang disampaikan oleh guru atau 
pendidik bisa dipahami siswa. Penggunaan pendekatan saintifik dalam pembelajaran juga bertujuan untuk mencapai suatu kompetensi.

\section{Daftar Pustaka}

"Andi Prastowo, Pembelajaran Konstruktivistik-Scientific... - Google Scholar." $\begin{array}{llll}\text { Diakses } & 9 & \text { Oktober }\end{array}$ https://scholar.google.co.id/scholar?hl=en\&as_sdt=0\%2C5\&q=Andi+Prast owo \%2C+Pembelajaran+Konstruktivistik-

Scientific+untuk+Pendidikan+Agama+di+sekolah\%2FMadrasah+\%E2\%8 0\%9CTeori\%2C+Aplikasi\%2C+dan+Riset+Terkait\%2C+\%28Jakarta\%3A + Raja+Grafindo+Persada\%3B+2015\&btnG $=$.

Arifin, Zaenal. "PENDEKATAN PEMBELAJARAN SAINTIFIK PADA MATA PELAJARAN BAHASA ARAB DI MADRASAH," t.t., 20.

Ayuni, Fithri Nuru. "PEMAHAMAN GURU TERHADAP PENDEKATAN SAINTIFIK (SCIENTIFIC APPROACH) DALAM PEMBELAJARAN GEOGRAFI." Jurnal Geografi Gea 15, no. 2 (25 Agustus 2016). https://doi.org/10.17509/gea.v15i2.3542.

Depdiknas, U. U., dan R. I. No. “Tahun 2003." Tentang Sistem Pendidikan Nasional, 20.

Fadhilaturrahmi, Fadhilaturrahmi. "PENERAPAN PENDEKATAN SAINTIFIK UNTUK MENINGKATKAN KEMAMPUAN KOMUNIKASI MATEMATIK PESERTA DIDIK di SEKOLAH DASAR." EduHumaniora | Jurnal Pendidikan Dasar Kampus Cibiru 9, no. 2 (13 Juli 2017): 109. https://doi.org/10.17509/eh.v9i2.7078.

Fajriana, Anggun Wulan, dan Mauli Anjaninur Aliyah. "Tantangan Guru Dalam Meningkatan Mutu Pendidikan Agama Islam Di Era Melenial." Nazhruna: Jurnal Pendidikan Islam 2, no. 2 (11 Agustus 2019): 246-65. https://doi.org/10.31538/nzh.v2i2.324.

"Farid Hasyim, kurikulum Pendidikan Agama Islam, Filosofi... - Google Scholar." $\quad$ Diakses $\quad 9 \quad$ Oktober 2019. https://scholar.google.co.id/scholar?hl=en\&as_sdt=0\%2C5\&scioq=Andi+ Prastowo\%2C+Pembelajaran+Konstruktivistik-

Scientific+untuk+Pendidikan+Agama+di+sekolah\%2FMadrasah+\%E2\%8 0\%9CTeori\%2C+Aplikasi\%2C+dan+Riset+Terkait\%2C+\%28Jakarta\%3A + Raja+Grafindo+Persada\%3B+2015\&q=Farid+Hasyim\%2C+kurikulum+ Pendidikan+Agama+Islam\%2C+Filosofi+Pengembangan+kurikulum+tran sformatif+Antara+KTSPdan+Kurikulum $+2013 \& b$ tnG $=$.

Fussalam, Yahfenel Evi. "IMPLEMENTASI KURIKULUM 2013 (K13) SMP NEGERI 2 SAROLANGUN" 3, no. 1 (2018): 11. 
Optimalisasi Pendekatan Scientific dalam Pembelajaran. . . | 221 - 222

Ghozali, Imam. "PENDEKATAN SCIENTIFIC LEARNING DALAM MENINGKATKAN PRESTASI BELAJAR SISWA” 04, no. 01 (2017): 13.

Gunawan, Heri. "Kurikulum dan Pembelajaran Pendidikan Agama Islam. cet." Ke-2. Bandung: Alfabeta, 2013.

. "Pendidikan Islam Kajian Teoritis dan Pemikiran Tokoh." Bandung: PT Remaja Rosdakarya, 2014.

Halim, Abdul. Filsafat Pendidikan Islam: Pendekatan Historis, Teoritis dan Praktis. Jakarta: Ciputat Pers, 2002.

Hosnan, M. Pendekatan saintifik dan kontekstual dalam pembelajaran abad 21: kunci sukses implementasi kurikulum 2013. Cet. pertama. Ciawi, Bogor: Ghalia Indonesia, 2014.

Kusaeri, Kusaeri, dan Rangga Sa'adillah. "Telaah Epistemologis Pendekatan Saintifik Mata Pelajaran Pendidikan Agama Islam." ISLAMICA: Jurnal Studi Keislaman 9, no. 2 (7 September 2015): 344-72. https://doi.org/10.15642/islamica.2015.9.2.344-372.

Ma`arif, Muhammad Anas, dan Muhammad Husnur Rofiq. "Pola Pengembangan Kurikulum Pendidikan Pesantren Berkarakter: Studi Pondok Pesantren Nurul Ummah Mojokerto.” TADRIS: Jurnal Pendidikan Islam 13, no. 1 (7 September 2018): 1-16. https://doi.org/10.19105/tjpi.v13i1.1635.

Machin, A. "Implementasi Pendekatan Saintifik, Penanaman Karakter Dan Konservasi Pada Pembelajaran Materi Pertumbuhan.” Jurnal Pendidikan IPA Indonesia 3, no. 1 (2014). https://doi.org/10.15294/jpii.v3i1.2898.

Meliana, Diyah Ery. "Diajukan kepada Universitas Negeri Surabaya Untuk memenuhi Persyaratan Penyelesain Program Sarjana Pendidikan Luar Biasa," t.t., 5.

Muhaimin, Nur Ali, Suti'ah, dan Siti Lailan Azizah. Paradigma pendidikan Islam: upaya mengefektifkan pendidikan agama Islam di sekolah. Remaja Rosdakarya, 2001.

Mulyasa, E. Pengembangan dan implementasi kurikulum 2013. Cetakan pertama. Bandung: PT Remaja Rosdakarya, 2013.

Nihayah, Ishmatun. "Pengembangan Kurikulum Bidang Studi Pendidikan Agama Islam Pada Program Akselerasi Di SMAN 5 Surabaya." Nazhruna: Jurnal Pendidikan Islam 1, no. 2 (19 November 2018): 312-23. https://doi.org/10.31538/nzh.v1i2.88.

Nur Hakim, Muhammad, dan Fitriyani Dwi Rahayu. "Pembelajaran Saintifik Berbasis Pengembangan Karakter." Nazhruna: Jurnal Pendidikan Islam 2, no. 1 (24 Februari 2019): 1-27. https://doi.org/10.31538/nzh.v2i1.148. 
Ridwan, Muhammad. "Konsep Tarbiyah, Ta'lim Dan Ta'dib Dalam Al-Qur'an.” Nazhruna: Jurnal Pendidikan Islam 1, no. 1 (16 Agustus 2018): 35-57. https://doi.org/10.31538/nzh.v1i1.41.

Rostika, Deti, dan Prihantini Prihantini. "PEMAHAMAN GURU TENTANG PENDEKATAN SAINTIFIK DAN IMPLIKASINYA DALAM PENERAPAN PEMBELAJARAN DI SEKOLAH DASAR." EduHumaniora | Jurnal Pendidikan Dasar Kampus Cibiru 11, no. 1 (31 Januari 2019): 86. https://doi.org/10.17509/eh.v11i1.14443.

Setiawan, Dika. "PENDEKATAN SAINTIFIK DAN PENILAIAN AUTENTIK UNTUK MENINGKATKAN MUTU PEMBELAJARAN PENDIDIKAN AGAMA ISLAM." AL-ASASIYYA: Journal Of Basic Education 1, no. 2 (10 November 2017). https://doi.org/10.24269/ajbe.v1i2.683.

Susilana, Rudi. "Pendekatan Saintifik dalam Implementasi Kurikulum 2013 Berdasarkan Kajian Teori Psikologi Belajar.” edutech 13, no. 2 (2014): 183-193.

- "PENDEKATAN SAINTIFIK DALAM IMPLEMENTASI KURIKULUM 2013 BERDASARKAN KAJIAN TEORI PSIKOLOGI BELAJAR." EDUTECH 13, no. 2 (12 Agustus 2014): 183. https://doi.org/10.17509/edutech.v13i2.3095.

Suyanto, Slamet. "The Implementation of the Scientific Approach through 5Ms of The New Curriculum of 2013 in Indonesia." Jurnal Cakrawala Pendidikan 37, no. 1 (8 Maret 2018). https://doi.org/10.21831/cp.v37i1.18719.

Wakhidah, Nur. "Pembelajaran Dengan Pendekatan Saintifik Terhadap Kemampuan Berpikir Kritis Mahasiswa Calon Guru Madrasah Ibtidaiyah." Premiere Educandum: Jurnal Pendidikan Dasar Dan Pembelajaran 8, no. 2 (18 Desember 2018): 150-60. https://doi.org/10.25273/pe.v8i2.2950.

Yarhamna, Yarhamna, Annisaul Khairat, Iskandar Fuaddin, dan Fismal Fismal. "PENGUJIAN PRAKTIKALITAS MODEL KEGIATAN EKSTRAKURIKULER PENDIDIKAN AGAMA ISLAM BERBASIS PENDEKATAN SAINTIFIK UNTUK SEKOLAH DASAR.” Ta'dib 22, no. 1 (29 Juni 2019): 13-18. https://doi.org/10.31958/jt.v22i1.1446.

Nasution, S., Kurikulum Dan Pengajaran, Jakarta: Bumi Aksara, 2010

Kurniasih, Imas, Berlin Sani, Sukses Mengimplementasikan Kurikulum 2013 Memahami Berbagai Aspek Dalam Kurikulum 2013, Jakarta: Kata Pena: 2014. 